\section{Microalgae: the next best alternative to fossil fuels after biomass. A review}

\section{Ritesh Bhagea, Vishwakalyan Bhoyroo, Daneshwar Puchooa}

\section{Agricultural and Food Science \\ Department, Faculty of Agriculture, University of Mauritius, Réduit, Mauritius}

\begin{abstract}
It is expected that $84 \%$ of the global energy demands will be met through fossil fuels in 2030 due to increasing energy needs. However, due to their impact on the environment through the emission of anthropogenic green house gases, biofuels were introduced as alternative sources of energy. Biofuels of plant origin for the transport sector proved to be controversial due to competition for food production, fertile land and expensive production processes. As a secondary alternative, microalgae such as Scenedesmus obliquus, Chlorella vulgaris and Nannochloropsis sp. were found to be suitable candidates for liquid biofuels production. This review describes the production of transportation liquid biofuels from plant biomass and microalgae. Information is provided on how the controversies related to plant biomass lead to the use of algal biomass. The production processes involved in both generations are discussed and highlighted. Furthermore, details on the production of secondary products such as pigments, feed additives and valuable secondary metabolites are also provided.
\end{abstract}

\section{Introduction}

Energy is one of the essential elements that is needed to sustain human survival and development. Since the mid- $18^{\text {th }}$ century, the invention of new technologies requiring high energy density input caused a sudden increase in the use of fossil fuels such as coal. ${ }^{1}$ Since then, the demand in energy in the form of fossil fuels has not dropped. ${ }^{2}$ It is known that these non-renewable sources of energy will be depleted but with the current state of oil reserves and based on the global demand, it is expected that crude oil supply will be adequate through $2050 .{ }^{3,4}$

The carbon dioxide generated from the use of such fuels has major negative impacts on the environment such as increased temperature resulting in water scarcity in dry regions, torrential rainfall in wet regions, melting glaciers increasing sea levels and stronger and more frequent heat waves. ${ }^{5-7}$ These are being caused by the increasing global temperature through the past 3 decades. ${ }^{8}$ With so many issues impacting the planet, it is a must to find reliable alternative sources of energy having long term positive effect such as biofuels.

In its early development through the $20^{\text {th }}$ century, the use of plant biomass was found to hold great potential in the form of biofuels. ${ }^{9}$ Bioethanol production from agricultural sources has demonstrated a lot of potential as a source of fuel with a prime example of Brazil blending ethanol, produced from sugarcane, to all of its gasoline to yield a $24 \%$ blend. ${ }^{10}$ Other non-food crops such as Arundo donax and Pongamia pinnata were sought but do not alleviate the issue of competition for food production. ${ }^{11}$ Moreover, it requires 1540 Mha of land to produce $172 \mathrm{~L} /$ ha of oil from corn which is in direct conflict with agricultural practices for food for consumption. ${ }^{12}$

Due to Due to greenhouse gas (GHG) emissions and food production issues, other environmental friendly sources such as microalgae were bound to be researched as the $3^{\text {rd }}$ generation biofuels. ${ }^{12}$ They are photosynthetic microorganisms synthesizing lipids and carbohydrates that can be used for biofuel production. ${ }^{13,14}$ Microalgae culture is considered as a carbon neutral process and does not compete with food crop production. ${ }^{15,16}$ In comparison to terrestrial crops, microalgae fuels have a higher yield of 30-100 times more energy per hectare of land used which is possible with the use of microalgaes such as Porphyridium cruentum and Scenedesmus dimorphus which can reach $40-57 \%$ and $21-52 \%$ carbohydrates on a dry matter basis, respectively. ${ }^{17}$ With respect to lipids, Nannochloropsis salina was found to reach $29 \%$ lipid content when cultured with wastewater supply. ${ }^{18}$

This review offers information on how the overuse of fossil fuels lead to the application of plant biomass firstly and then microalgae for biofuels production. The various sources of plant biomass and the major processes involved in the production chain are introduced along with the impacts of their use. For the algal biomass section, the currently used microalgae strains, culture conditions and biomass processing techniques are extensively developed with additional information on the other uses of microalgae.

\section{Fossil fuels}

\section{Primary source of energy}

Due to the unavailability of the conditions that existed millions of years ago that
Correspondence: Ritesh Bhagea, Agricultural and Food Science Department, Faculty of Agriculture, University of Mauritius, Réduit, Mauritius.

Tel.: +230.57934668

E-mail: ritesh.bhagea@gmail.com

Key words: Fossil fuels; Biomass; Microalgae; Bioethanol; Biodiesel.

Contributions: the authors contributed equally.

Conflict of interest: the authors declare no potential conflict of interest.

Funding: the authors would like to thank the University of Mauritius for the funding of the research project.

Received for publication: 14 November 2018. Revision received: 26 February 2019.

Accepted for publication: 26 February 2019.

This work is licensed under a Creative Commons Attribution NonCommercial 4.0 License (CC BY-NC 4.0).

\section{(C) Copyright R. Bhagea et al., 2019}

Licensee PAGEPress, Italy

Microbiology Research 2019; 10:7936

doi:10.4081/mr.2019.7936

transformed organic material into fossil fuels, it was made evident that the latter are bound to be completely exhausted as they are non renewable. ${ }^{19}$ It has been envisaged that in the next 30 years, petroleum will no longer be available. ${ }^{3}$ However coal, oil and natural gas are currently the major sources of energy satisfying the global demand. ${ }^{20}$ It is estimated that the demand in oil will increase to $103.8 \mathrm{mb} / \mathrm{d}$ by 2022 from an initial average of $96.6 \mathrm{mb} / \mathrm{d}$ in $2016 .{ }^{4}$ Moreover, it is expected that fossil fuels will continue to meet up to $84 \%$ of the energy demand in $2030 .^{21}$

Demands in oil and gasoline have been increasing for decades in various countries. In the case of Brazil, gasoline consumption grew at a rate of $7.5 \%$ from 1990 to $1999 .{ }^{22}$ Similar trends were observed in countries like Lebanon and China in the past decade. ${ }^{23}$ These surges in fuel demands can be accounted to the growth of car imports and the growth in the population requiring more energy such as electricity in countries like Brazil and Senegal.22,24 All of such demands are met through global supplies but many producing countries such as Iran have gone beyond their fuel production capacities due to high levels of subsidiaries and very low prices of fuels. ${ }^{25}$ This results in a very high local use and demand of the fuels. 


\section{Impact on health and environment}

The utilization of fossil fuels has been subject to various controversies following the discovery of the global warming effect and $\mathrm{GHG}$ emissions. ${ }^{26} \mathrm{CO}_{2}$ dominates the entirety of the GHGs by $90 \% .{ }^{27}$ The two major sectors impacting the $\mathrm{CO}_{2}$ emissions are electricity \& heat (42\%) and transport (24\%). ${ }^{27,28}$ In 2015, the global $\mathrm{CO}_{2}$ emissions reached $32.3 \mathrm{GtCO}_{2}$ compared to 32.2 $\mathrm{GtCO}_{2}$ in 2013. Although the increase seems very small, the consequences of the emissions are still having a destructive influence on society and the environment. In 2012, there were 3.7 million deaths due to ambient air pollution on the planet. $^{29}$ Impacts on the environment were identified as follows; dry regions experiencing water scarcity due to increased temperature, torrential rainfall occurring in wet regions, and more frequent heat waves. ${ }^{5-7}$ Sea levels are increasing due to melting glaciers with sea height variations of $21.6( \pm 0.80) \mathrm{mm}$ in February 2000 rising to $89.9( \pm 0.80) \mathrm{mm}$ in October $2018 .{ }^{30}$ These are being caused by the increasing global temperature through the past 3 decades. ${ }^{8}$

Another factor contributing to high $\mathrm{CO}_{2}$ emissions is ssubsidiary. The high levels of fuel subsidiaries in countries like Iran and Saudi Arabia, which are part of the Middle East and North Africa and which are considered as the largest contributors to $\mathrm{CO}_{2}$ emissions, renders the current situation of global warming difficult to overcome. ${ }^{31}$ This drives the aspect of efficient energy use and production of energy efficient goods out of context and the same situation applies to renewable energy industries. ${ }^{32}$

The Kyoto Protocol in 1998 and the 2015 Paris Climate Conference were initiated to implement and elaborate policies and measures to reduce $\mathrm{CO}_{2}$ emissions and keeping global warming below $2{ }^{\circ} \mathrm{C} .{ }^{33,34}$ For the transport sector, a lot of research is being done to reduce $\mathrm{CO}_{2}$ emissions in the long term through the enforcement of poli- cies and counter measures. ${ }^{35,36}$ However, due to their slow impact, ${ }^{37}$ the most suitable method is to attack the current issue by modifying the fuel in use itself through the production of biodiesel and bioethanol., 9,38 When the conflicts between increasing fuel demands and environmental issues were identified, 2 strategies were evaluated; modifying engines according to the fuel or modifying the fuel to the engine. However, it proved to be too costly to produce such engines and their selling prices were very high due to low production numbers. ${ }^{9}$ Therefore, the use of bioethanol in gasoline and biodiesel in diesel remain the cheaper alternative. ${ }^{39}$

\section{Biofuels: $1^{\text {st }}$ and $2^{\text {nd }}$ generations \\ Production status}

In the meantime, research was already ongoing with the objective to seek alternative sources of fuels. Biofuels such as bioethanol and biodiesel were found to be among the most promising and attractive solutions to the replacement of fossil fuels in the transportation sector. ${ }^{40}$ First generation biofuels are primarily derived from crop plant products such as sugar and starch for ethanol while vegetable oils and animal fats for biodiesel production. ${ }^{41,42}$ The major plants investigated and utilized were sugar cane, corn and wheat for ethanol while palm oil, sunflower seeds, castor seeds, rapeseed and soybean for biodiesel among many others. ${ }^{43-45}$

In 2016, the global biofuel production reached a rate of $2.35 \mathrm{mb} / \mathrm{d}$ and represented $4 \%$ in terms of world road transport fuel. Ethanol production in 2016 was at 1.73 $\mathrm{mb} / \mathrm{d}$ while that of biodiesel was recorded at $620 \mathrm{~kb} / \mathrm{d}$. With annual growths of $2.5 \%$ and $4 \%$ for ethanol and biodiesel, it is expected that the global output by 2022 will reach the $2 \mathrm{mb} / \mathrm{d}$ and $800 \mathrm{~kb} / \mathrm{d}$ respectively. ${ }^{4}$ Forecasts (Table 1) on the global production are crucial in the advancement of biofuels as a mean against global warming.

In the US, the average retail prices of biofuel blends E85, B20 and B99/B100 recorded on first January 2018 were $\$ 2.68$, $\$ 2.55$ and \$3.41 per gallon respectively. However, when compared to the gasoline (\$2.50/gallon) and diesel (\$2.63/gallon), the prices of biofuel blends are higher. ${ }^{46}$ The prevailing trend is that the higher the blend used, the higher the price. This situation is due to the fact that liquid biofuels provide less energy density in comparison to fossil fuels when measured in equivalent units. Therefore, more fuel is needed to cover distances and thus creates more demands in ethanol and diesel. Additional contributing factors are lack of financial support and international trade barriers. ${ }^{47}$ Financial support as subsidiaries has greatly helped Thailand in 2008 where E85 was $30-40 \%$ cheaper than gasoline. ${ }^{48}$ However, this scenario cannot be resolved with the use of food crops for biofuels as it is a highly debatable topic, which has a major impact on the price on biofuels. As it is, availability of the feedstock on the market according to seasonal patterns is very important as it dictates the price of the resulting biofuel. ${ }^{49}$

\section{Agricultural point of view: plants for food or fuels?}

The world population is currently at 7.6 billion and is increasing. ${ }^{2}$ With so many individuals to feed, it is imperative that agricultural productivity be increased by $70 \%$ to meet demands for food in $2050 .{ }^{50}$ Developing countries are faced with social and economic issues on the use of food crops for fuel or for consumption. ${ }^{51,52}$ Producing biofuels using food commodities decreases the availability of these commodities on food markets. This results in a chain reaction where the prices of these products increase and thus causes more land to be brought into production leading to an increase in biodiversity loss. ${ }^{53,54}$

Table 1. The global ethanol and biodiesel productions recorded in 2016 from major countries and predictions for $2022 .{ }^{4}$

\begin{tabular}{|c|c|c|c|c|}
\hline Biofuel & Country & Major feedstock(s) & Production for $2016(\mathrm{~kb} / \mathrm{d})$ & Forecast for $2022(\mathrm{~kb} / \mathrm{d})$ \\
\hline Ethanol & $\begin{array}{l}\text { United States } \\
\text { Brazil } \\
\text { China } \\
\text { OECD Europe } \\
\text { India } \\
\text { Thailand } \\
\text { United States } \\
\text { Brazil }\end{array}$ & $\begin{array}{l}\text { Corn } \\
\text { Sugarcane } \\
\text { Corn } \\
\text { Corn, wheat, sugar beet } \\
\text { Molasses } \\
\text { Molasses } \\
\text { Soybean } \\
\text { Soybean }\end{array}$ & $\begin{array}{c}990 \\
470 \\
50 \\
80 \\
19 \\
21 \\
98 \\
66\end{array}$ & $\begin{array}{c}1015 \\
620 \\
65 \\
115 \\
36 \\
40 \\
125 \\
90\end{array}$ \\
\hline Biodiesel & $\begin{array}{l}\text { OECD Europe } \\
\text { Indonesia } \\
\text { Malaysia } \\
\text { Argentina }\end{array}$ & $\begin{array}{l}\text { Hydrogenated vegetable oil } \\
\text { Palm oil } \\
\text { Palm oil } \\
\text { Soybean }\end{array}$ & $\begin{array}{c}227 \\
50 \\
15 \\
50\end{array}$ & $\begin{array}{l}270 \\
110 \\
24 \\
60\end{array}$ \\
\hline
\end{tabular}


Improving biofuel output per area of land can be considered only as a small fragment of a solution for increasing energy efficiency per unit area of biomass. ${ }^{55}$ However, food provision and bioenergy cannot be treated in isolation from one another. To address this situation, the application of Integrated Food Energy Systems (IFES) where liquid biofuels, food and energy are all simultaneous produced seems promising. ${ }^{56}$ The concept of intercropping various species of crop plants such as maize, pigeon peas and sorghums is a potential way of assuring food production, land use and residual biomass conversion to biofuels. ${ }^{56}$ However, it is still a risky business when there are natural disasters. Between 2003 and 2013, 78 natural disasters occurred across the globe causing a total of $\$ 30$ billion of damages to agriculture. ${ }^{57}$ Moreover, there are 925 million people that are undernourished and thus the focus with food production is driven to food security concerns. ${ }^{58}$

\section{The $2^{\text {nd }}$ generation biofuels Lignocellulosic biomass for ethanol}

Biofuel production from starch-rich materials and food crops proved to be inefficient for large scale biofuel production due to the increase in food commodity prices, competition for food and land for crop plantation. ${ }^{53}$ However, non-food crops and plant-based materials were found to be potential candidates in the form of lignocellulosic materials such as wood, paper, agricultural residues and specific energy crops. ${ }^{59}$ These materials are easily available, renewable and inexpensive for the production of bioethanol. ${ }^{60,61}$ They consist mainly of cellulose and hemicellulose which are the sources of carbohydrates. ${ }^{62,63}$

As mentioned earlier, lignocellulosic biomass can be from agricultural residues as well as non agricultural products. Non agricultural products and plant-based materials include newspapers, hardwood and softwood among many others. ${ }^{64}$ Agricultural residues consist of sugarcane bagasse, corn cod, corn stover and other non crop-plants such as spruce, Arundo donax and switch grass. ${ }^{60,65-69}$ Lignocellulosic ethanol production starts with biomass pretreatment, hydrolysis, fermentation, distillation and drying. ${ }^{70}$ Improvements to the processes lead to a more complex production system. ${ }^{60,71,72}$ Following pretreatment, the biomass undergoes two further steps, hydrolysis and fermentation (Figure 1). The implementation of the technology on industrial scale is yet unknown. ${ }^{73}$ However, even though lignocellulosic biomass has proved to hold enough potential for ethanol production and that it does not compete directly with food production, it still does require land for cultivation. This triggers once again the debate on land use for food production over fuel production.

\section{Non-edible crops for biodiesel}

The first generation of biodiesel came mainly from edible vegetable oils of soybeans, palm oil, rapeseed, peanut and coconut. Other sources include the non-edible vegetable oil (Jatropha curcas, Croton megalocarpus, Pongamia pinnata), waste or recycled oils and animal fats. ${ }^{74-77}$ The world biodiesel production is generated from edible oils at more than 95\% (rapeseed at $84 \%$ and sunflower oil at $13 \%$ ) with increasing production values over the years (Table 2). ${ }^{78}$ The US cultivates soybean extensively as a biodiesel feed stock as well as food source but can only meet $6 \%$ of the energy demands. ${ }^{79}$

The production of biodiesel depends on the methods used, including transesterification, thermal cracking and micro-emulsions. ${ }^{81,82}$ The basic process in biodiesel production is the transesterification step (Figure 2) where fatty acids (triglycerides) are converted into methyl esters (biodiesel). Nowadays, with engine developments and improved biodiesel processing, the US manufactures B100, B20, B5 and B2 biodiesel blends for accentuated efficiency and combustion. ${ }^{83}$ Combinations of oils of various origins are also evaluated for their performance as fuels.

\section{Microalgae: the $3^{\text {rd }}$ generation biofuel}

\section{Better than plants}

With all of the mentioned issues on the use of crops for biofuels production, the next promising resource was found to be microalgae. Microalgae have been receiving a lot of attention due to their characteristics in terms of high lipid and carbohydrate contents and applications. ${ }^{84}$ These photoautotrophs have existed for billions of years capturing $\mathrm{CO}_{2}$ and thus provided suitable conditions for life to exist and evolve. ${ }^{17}$ Even though microalgae thrive on land and in aquatic environments, there are only 30,000 species that are currently known. ${ }^{85}$ They exist as both prokaryotes and eukaryotes consisting of a total of 11 divisions of which the groups Cyanophyceae (blue-green algae), Chrysophyceae (golden algae) and Chlorophyceae (green algae) are the mostly exploited ones. ${ }^{13}$ With the issues of second generation biofuels production such as land use, costly pretreatments for lignin removal

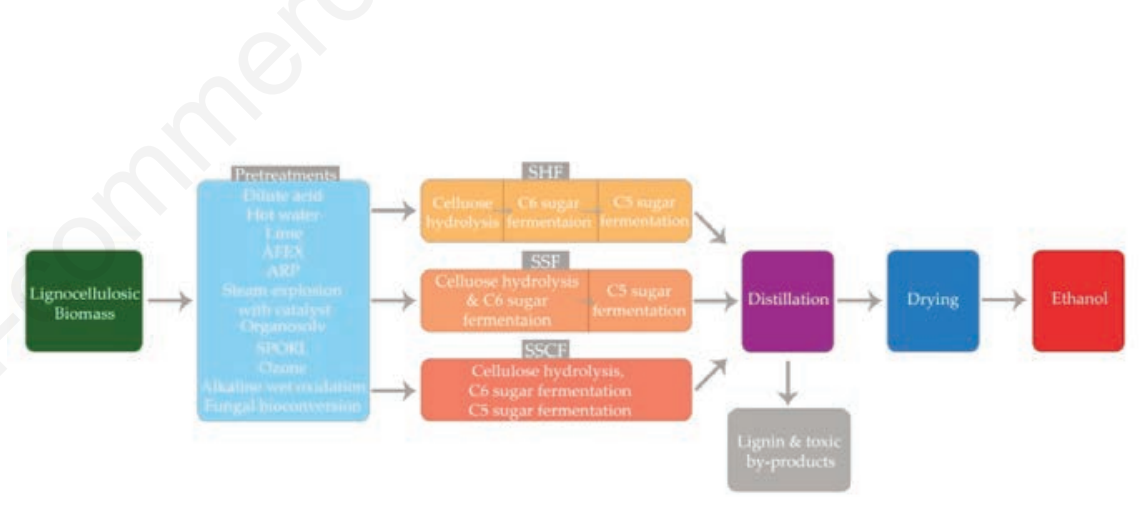

Figure 1. Flow diagram illustrating the different pretreatments and pathways involved in bioethanol production from lignocellulose biomass. ${ }^{70,74}$ SHF: separate hydrolysis and fermentation; SSF: simultaneous saccharification and fermentation; SSCF: simultaneous saccharification and co-fermentation.

Table 2. Annual global production values of some biofuel feed-stocks. ${ }^{80}$

\begin{tabular}{lccc} 
Feedstock & \multicolumn{3}{c}{ Production per year (Mit) } \\
Soybean & 2000 & 2010 & 2016 \\
Castor oil & 161.3 & 264.9 & 334.9 \\
\hline Coconut & 1.4 & 1.7 & 1.8 \\
Palm oil & 51.2 & 60.1 & 59.0 \\
\hline Rapeseed & 22.2 & 45.8 & 0.0 \\
Safflower & 39.6 & 59.9 & 68.9 \\
\hline
\end{tabular}


and food crop productions, microalgae offer a more convenient approach to alleviating the supply of biofuels as they do not possess lignin. ${ }^{86}$

Just like plants, these organisms can produce carbohydrates, lipids and proteins as well as other interesting compounds such as astaxanthin and $\beta$-carotene. ${ }^{87}$ The cellular contents of microalgae vary from species to species (Table 3). Microalgae can synthesize between $30-70 \%$ of oil (by weight) in biomass. This particular characteristic makes these microalgae suitable candidates for biodiesel production. In comparison to production values, corn requires 1540 Mha of land to produce $172 \mathrm{~L} /$ ha of oil while microalgae would need 2 Mha of land area to yield $136900 \mathrm{~L} /$ ha of biodiesel. ${ }^{12}$

Similar trends can be observed with bioethanol production as joint productions of both biofuels have been successful with microalgae. ${ }^{88-94}$ Scenedesmus abundans was investigated as a potential candidate for bioethanol production reaching a productivity of $0.103 \mathrm{~g}$ of bioethanol per gram of dry weight algae. ${ }^{95}$ It is safe to say that microalgae are the best potential sources of biofuels at the moment.

\section{Nutrition and culture conditions}

The concentrations of the various biochemical compounds within the microalgae are highly dependent on the environment. It is already known that changes in the environment such as light, temperature and nutrients affect the growth of microalgae and the accumulation of carbohydrates, proteins and lipids. ${ }^{96}$ The basic parameters for microalgae culture consist of a light source, temperature between $16-27^{\circ} \mathrm{C}, \mathrm{pH}$ ranging between $7-9$ and salinity between $20-24 \mathrm{~g} / \mathrm{L}$ and mixing. ${ }^{13}$ Incapacity to provide optimal conditions can result in the culture collapsing or poor growth.

\section{Effect of lighting parameters}

Microalgae are photosynthetic organisms and thus require light to thrive. Typically, the light intensity used varies between 100 and $200 \mu \mathrm{E} \mathrm{sec}-1 \mathrm{~m}^{-2}$ for productions depending on strains used. ${ }^{13}$ The effect of light source is limiting especially in terms of biomass production. ${ }^{97}$ During culture, the higher the intensity (within permissible limits), the higher the penetration power of the light across the culture vessel and media. This was observed with Dunaliella viridis where irradiance was not powerful enough to allow cells to photosynthesise at a depth above $10 \mathrm{~cm} .{ }^{98}$ The use of higher intensities can result in energy wastage and ultimately costs. This can be explained with respect to cells being unable to process light energy to biochemical ener- gy. The excess energy is dissipated as heat to the environment. ${ }^{99}$ Many attempts to modulate the effects of light on microalgae culture are ongoing. Trials aiming at optimising the effect of photoperiod (light/darkness) are also ongoing. The most widely used settings are $12 \mathrm{~h}: 12 \mathrm{~h}, 14 \mathrm{~h}: 10 \mathrm{~h}$ or 24h:0h. It must be pointed out that photoperiods are essential for the production of ATP and NADPH during photosynthesis. Darkness allows the cells to produce biomolecules important for growth. ${ }^{100}$

The growth rate is also dependent on temperature for optimal lipid production. ${ }^{101}$ Temperature is a very special parameter to observe as rises in the latter can be due to lighting, surrounding heating elements and other sources. Though normally ambient temperature is preferred for microalgae culture, it has been shown that this particular parameter may have inverse relationships with certain microalgae. ${ }^{102}$ The manipulation of these specific parameters have been reported as beneficial for certain metabolite production. ${ }^{103}$

\section{Effect of nitrogen and phosphorus}

Microalgaes prefer nutrient-enriched environments for growth and lack of nutrients can be detrimental as this is well observed in cyanobacteria. They tend to change structure and composition in communities in such situations. ${ }^{104}$ Stress conditions on microalgae cultures of some species have also shown increased carbohydrates or lipids synthesis and vary from species to species. Aspects relating to stress conditions has been reviewed. 105 Microalgae such as Chlorella vulgaris and Scenedesmus obliquus were used as model organisms to evaluate the effect of nitrogen and phosphorus availability on biochemical composition and biomass yield. The effects showed that $S$. obliquus can accumulate more phosphorus $(\mathrm{P})$ than $C$. vulgaris while the latter accumulates more nitrogen $(\mathrm{N}) .{ }^{106}$ Nutrient starvation is a well known process which involves the accumulation of carbohydrates or lipids due to the metabolism of proteins. ${ }^{107}$ However, some microalgae are not tolerant to such conditions and can



Figure 2. Transesterification reaction of oils to biodiesel.

Table 3. Biochemical characteristics of researched microalgae species (according to research parameters applied).

\begin{tabular}{lcccc}
\hline Microalgae species & Lipids & Proteins & Total Carbohydrates & Refis. \\
Arthrospira platensis & 8.1 & 62.9 & 15.6 & 88 \\
Chlamydomonas reinhardtii & 21.0 & 48.0 & 17.0 & 17 \\
\hline Chlorella sp. MP-1 & 28.8 & 43.2 & 19.5 & 89 \\
Chlorella vulgaris & 2.0 & 57.0 & 26.0 & 90 \\
\hline Chlorogloeopsis fritschii & 7.0 & 50.0 & 44.0 & 91 \\
Dunaliela salina & 9.1 & 5.4 & 69.7 & 92 \\
\hline Dunaliela tertiolecta & $18.0-23.5$ & $8.3-31.3$ & $46.5-50.6$ & 92 \\
Nannochloropsis sp & 8.1 & 16.7 & - & 93 \\
\hline Porphyridium cruentum & $9.0-14.0$ & $28.0-39.0$ & $40.0-57.0$ & 90 \\
Scenedesmus dimorphus & $16.0-40.0$ & $8.0-18.0$ & $21.0-52.0$ & 17 \\
Tetraselmis maculata & 3.0 & 52.0 & 15.0 & 17 \\
\hline
\end{tabular}


result in poor biomass productions. Nannochloropsis sp. was found to yield a low biomass upon $\mathrm{N}$ and $\mathrm{P}$ limitations as the interactive effects that these components have affect the lipid content. ${ }^{108}$

Lipid accumulation can result for the conversion of the cellular-N pool (proteins) or by modifying their bio-synthetic pathways upon $\mathrm{N}$ deficiency in the media and excess of P. Therefore, hypothetically, for improved lipids productions, it is best to operate under batch conditions with excess P with Nannochloropsis sp. This scenario could improve biodiesel productions. Under similar stress conditions, carbohydrate content can also be amplified. This was observed with the microalgae Chlorella vulgaris where carbohydrate accumulation peaked at $22.4 \%$ compared to $16.0 \%$ under N-limitation. ${ }^{96}$ Similar results were obtained with microalgae in the Chrysophyceae class, but the lack of $\mathrm{N}$ resulted in a low biomass even though the carbohydrate content was higher. ${ }^{97}$ Microalgae are targeted for the production of biodiesel more than bioethanol due to their high lipid content. ${ }^{76}$

\section{Types of culture}

Microalgae culture can be done in different ways such as photoautotrophic, heterotrophic and mixotrophic. ${ }^{109}$ Photoautotrophy is the most commonly employed method for microalgae cultivations, and is present in the use of open pond and closed photobioreactor systems. ${ }^{110}$ This type of culture operates by using light as energy source, $\mathrm{CO}_{2}$ from the surface air and presence of aerators in artificial ponds. ${ }^{111}$ The microalgae grow by conducting photosynthesis where energy from the light source is stored as ATP and NADPH. They are then processed through the Calvin cycle to generate glucose as the energy source. This type of culture is the most economic one as it utilises sunlight as energy source. However, this criterion is also a limiting factor considering that photosynthesis will only occur in the presence of light. Artificial lightning is a means to counter this issue but is very costly to implement and run. It must be noted that microalgae culture is very diverse and culture systems must be carefully used depending on the desired end product.

Heterotrophy is different in the sense that an organic carbon source is present in the media and then absorbed and metabolized by the microalgae. The biomass yield is much higher and does not require light. The major carbon source used is normally glucose but can also include peptone and acetate. ${ }^{109}$ The main disadvantages that this type of culture offers are the costs associat- ed with the supply of the carbon source and potential contamination with bacteria/fungi. Growth of Cyclotella cryptica was recorded in heterotrophic conditions with glucose as carbon source. The cellular carbohydrate, protein and lipids contents were $360 \mathrm{mg} / \mathrm{g}$, $260 \mathrm{mg} / \mathrm{g}$ and $165 \mathrm{mg} / \mathrm{g}$ respectively. ${ }^{101} \mathrm{~A}$ variation of heterotrophy is photoheterotrophy which is a culture condition where light is needed to activate Photosystem I while using sugar as the exclusive carbon source. ${ }^{109}$ Each of these culture conditions has its advantages and disadvantages regarding the light and carbon sources, biomass yield and costs. However, depending on the goal of the culture, whether it is for biofuel production, feed production, or other applications, the condition will depend on the microalgae strain, investments and desired end product.

Mixotrophic systems occur where photosynthesis occur in the presence of organic compounds and $\mathrm{CO}_{2} \cdot{ }^{109}$ In fact, it involves two stages: preliminary stage of heterotrophy due to high organic carbon content followed by photoautotrophy in the second stage. ${ }^{112}$ Culture of $C$. vulgaris under mixotrophic conditions yielded $140 \%$ and $170 \%$ of biomass and lipids respectively over autotrophic growth. ${ }^{113}$ Arthrospira platensis reached a biomass concentration of $1.3 \mathrm{~g} / \mathrm{L}$ when grown in glucose and under continuous lightning. ${ }^{110}$

\section{Mass production: current technologies Open (raceway) ponds}

The industrial production of microalgae can be achieved with two types of culture systems: open systems (raceway ponds Figure 3) and closed systems (PBRs - photobioreactors). ${ }^{114}$ Open bioreactors offer the most economic aspect of microalgae culture with respect to constructions, maintenance and operation although, issues such as contamination, evaporation and land requirements persist. On the other hand, closed PBRs offer a more convenient approach to deal with evaporation and contamination but constructing closed culture vessels is costly. ${ }^{115}$

In the choice of culture systems, it is not only the microalgae strain that is important but also the reason for the culture. In case of biofuel production, culture should preferably rely solely on freely available sunlight irrespective of weather conditions to be economically viable. ${ }^{12}$ Many factors have been identified as potential threats to microalgae culture such as light source, nutrients, temperature and others as discussed in the Nutrition and culture conditions section. For pilot-scale and commercial scale productions, raceway ponds remain the easiest and most applicable option due to the ease of setup. ${ }^{116}$ Raceway ponds basically consist of a closed and looped channel that is driven by a paddle wheel while the liquid flow is guided by baffles. $^{12}$ The whole system is exposed to sunlight and the paddle wheel operates to prevent the occurrence of sedimentation. Due to their simple assembly, raceway ponds can be easily scaled up. ${ }^{117}$ The supply of $\mathrm{CO}_{2}$ is an excellent method of aeration and helps increase biomass production. ${ }^{118}$ These ponds are usually shallow to allow

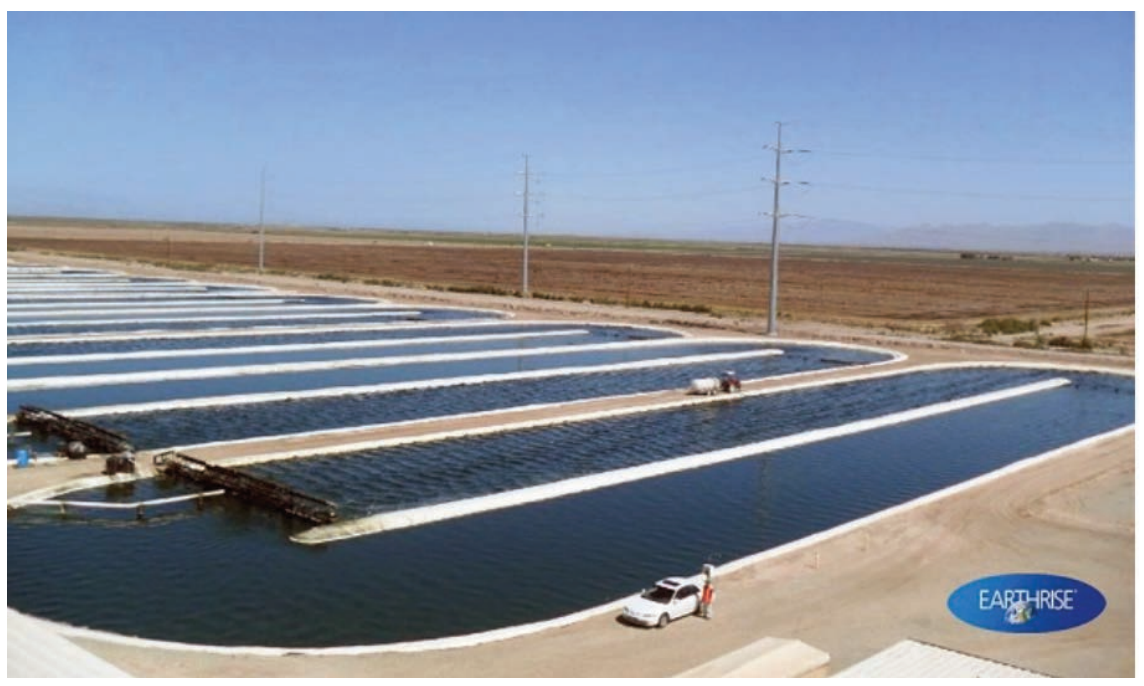

Figure 3. Spirulina culture in open raceway ponds at Earthrise $^{\odot}$ company, US. (Permission granted for use of photo). 
light penetration. ${ }^{115}$ The set up of such ponds does not necessitate fertile lands which is a strong point. A different type of open pond is the circular pond that operates with a rotating arm that mixes the culture and is very shallow (around $5 \mathrm{~cm}$ ). They are still used in Japan, Taiwan and Indonesia. ${ }^{119}$ However, these types of reactors are susceptible to contaminants and also result in low biomass productions. ${ }^{120}$

\section{Closed photobioreactors}

Due to low productions and contaminations, closed PBR systems were created including tubular PBR, flat-plate bioreactor and column PBRs. ${ }^{121}$ Tubular PBRs such as stirred tank and bubble column are suitable systems used to reduce contamination and improve biomass productions. Mixing is achieved through the bubbling of $\mathrm{CO}_{2}$ at the bottom of the vessel via air pumps. ${ }^{122}$ This type of PBR does allow control over culture conditions such as good mixing, high photosynthetic efficiency and low energy consumption but is limited to heterotrophic microalgae and this is not desired in microalgae based biofuels. ${ }^{115}$ Another challenge with this type of PBR is the difficulty to scale up, especially in vertical tubular PBR where costs are required for support systems and the high quality construction materials. ${ }^{123}$

Tubular PBRs are designed in a way so as to reduce the light path and thus increase the availability of light to the microalgae cells. Additionally, modulating the pipe diameter is also crucial as larger pipes would provide higher liquid velocity which could potentially damage cells and the opposite will result in poor biomass production. ${ }^{124,125}$ Flat plate PBRs are used for large scale production of microalgae outdoors and indoors due to the high illumination surface area and ease for scaling up compared to tubular PBRs. ${ }^{123}$ However, in this culture system it is difficult to control the temperature and is also subject to biofouling. ${ }^{126}$ Column PBRs offer a high mass transfer capacity, are easy to sterilize and provide good mixing with acceptable shearing forces. However, the costs associated in the material for construction is very high and uses a lot of energy when operating making it less desirable. ${ }^{115}$

\section{Biomass harvesting}

Harvesting microalgae post culture is a very difficult task due to the size of the cells. It is estimated that at least a quarter of the production costs is incurred from the harvesting processing as they are mostly energy driven or require costly chemicals. ${ }^{120}$ There various harvesting techniques that are currently available and/or in devel- opment which consist of physical, chemical, flocculation, bio-flocculation and electrophoretic methods. ${ }^{127}$ The main purpose of these processes is to dewater the microalgae slurries. ${ }^{128}$ Sedimentation is a physical technique that works on gravitational force. The cells sediment based on density differences and work best in sedimentation tanks as the bottom area forms an inverted conical shape. However, this technique is a very slow process as microalgae cultures share similar densities to water. ${ }^{129}$ It took $2 \mathrm{~h}$ for $S$. dimorphus and Chlorella vulgaris to reach a biomass recovery of $80 \%$ and $55 \%$ respectively. ${ }^{130}$ Similar results were obtained with C. fusiformis and Nannochloropsis sp. after a settling time of $24 \mathrm{~h} .{ }^{131}$

Filtration is another technique that allows rapid flow of culture through a porous membrane (pore size $\approx 0.001$ to $10 \mu \mathrm{m})$ and the cells are retained. The recovery rates with filtration are very high but the process is also very costly. ${ }^{111}$ Centrifugation is a method which operates on recovering solids from liquids through centrifugal force by high speed spinning. Biomass recovery rates can reach above $95 \%$ with centrifugation but this technique as well is very expensive. ${ }^{132,133}$ Flocculation consists of coagulating microalgae cells by flocculants agents such as chitosan. ${ }^{134}$ This functions by the neutralization of the charges on the cells and the reduction of the intercellular repulsion forces leading to the cells to aggregate. ${ }^{135}$ Successful harvesting of Chlorella vulgaris was reported with chitosan. ${ }^{136}$ This technique depends on various parameters such as flocculant used, algae species and cell size. ${ }^{137}$ Bio-flocculation is another form of flocculation where flocculating microalgae are used to concentrate non-flocculating microalgae with examples such as Ankistrodesmus falcatus, Scenedesmus obliquus and Tetraselmis suecica. ${ }^{138}$ Bio-flocculation can also involve microorganisms other than microalgae such as Peranema trichophorum. ${ }^{139}$ Harvesting techniques should be chosen according to costing involved and the end product desired.

\section{Biomass conversion}

Following biomass collection, the latter is subjected to downstream processing which consists of cell disruption to release the components of interest such as lipids and carbohydrates for biofuels production. ${ }^{140}$ Pretreatment methods include sonication, microwaves, bead beating and freezing. ${ }^{141}$ On large scales, such pretreatment methods would preferably be chemical hydrolysis as the chemicals used are more economical than ultrasonication or freezethawing. ${ }^{141-143}$ Acid hydrolysis of S. obliqu- us yielded a sugar concentration of $95.6 \%$ making it a single step pretreatment requirement. ${ }^{141}$ Another study with Tribonema sp. gave a carbohydrate yield of $81.48 \%$ upon acid hydrolysis. ${ }^{94}$ Acid hydrolysis is the better technique considering that microalgae do not possess cell walls compared to lignocellulosic biomass. ${ }^{86,144}$ There are 3 main types of post pretreatment processes used to convert microalgae biomass into suitable fuels: chemical, biochemical and thermochemical conversion. ${ }^{17,145}$ The chemical and biochemical pathways are used primarily for the production of biodiesel and bioethanol respectively.

The chemical process refers to the transesterification of triglycerides to methyl esters. This reaction is very similar to that encountered in the biodiesel production from plants. The triglycerides are abundant in microalgae in the form of lipids and fatty acids which normally serve as source of energy and storage products. ${ }^{17}$ The oil content of microalgae ranges from $30-70 \%$ of dry weight as it varies from species to species. ${ }^{12}$ Triglycerides of interest would be those with chain lengths of $\mathrm{C} 15-\mathrm{C} 22$ and low levels of unsaturation. Microalgae can synthesize hydrocarbons that posses straight chains and this improves the cetane number of the resulting biodiesel. However, due to isomerism, these hydrocarbons can be affected by cold weather and thus it is most likely that biodiesel be used for blending with petroleum fuels. ${ }^{130}$ As it is, biodiesel and diesel have similar properties such as cetane number, flash point and viscosity. ${ }^{146,147}$ Additionally, crude microalgae oil contains high levels of $\mathrm{P}, \mathrm{N}$ and metals which may affect the resulting biodiesel such as NOx emissions. Further research should be oriented towards the purification of the crude oil before biodiesel productions. ${ }^{130}$ S. obliquus and S. platensis were investigated as a candidate for biodiesel and the characteristics of the oil produced was in conformation to the biodiesel standard specifications. ${ }^{148,149}$

The biochemical process is mainly dedicated to the production of bioethanol through fermentation. Carbohydrates such as sucrose are first hydrolyzed to release glucose and fructose by the activity of the enzyme invertase. Then, the fermentation of the simple sugars, glucose and fructose, is performed by the yeast such as Saccharomyces cerevisiae to produce ethanol. ${ }^{17}$ During the early 2000s, the lack of suitable microorganisms for industrial fermentation was already an issue and engineering bacteria such as Escherichia coli and Zymomonas mobilis was then put forward for efficient fermentation of sugars. ${ }^{150}$

Microalgae hydrolysates have been suc- 
cessfully fermented to produce ethanol at a concentration of $8.55 \mathrm{~g} / \mathrm{L} .{ }^{86}$ The joint production of biofuels is also feasible as microalgae contain both carbohydrates and lipids. Depending on microalgae used, high levels of both biofuels can be obtained. The filamentous microalgae Tribonema sp. was successfully used to produce both biodiesel and bioethanol. ${ }^{94}$ Bioethanol was also produced from Chlorella vulgaris at a yield of $89 \%$ using continuous immobilized yeast fermentation. ${ }^{96}$

\section{Biomass processing}

Thermochemical processing of microalgae biomass is divided into 4 categories: liquefaction, torrefaction (combustion), pyrolysis and gasification. ${ }^{145}$ Liquefaction or hydrothermal liquefaction (HTL) is the production of bio-oil by the reaction of the biomass in water at temperatures ranging between $200-300^{\circ} \mathrm{C}$ and at high pressure with the possible input of catalyst. The advantage of this process is that it does not require dewatering the algal biomass. ${ }^{151}$ The biomass is converted into liquefied products following physical and chemical changes in a complex sequence. ${ }^{76} \mathrm{HTL}$ of Nannochloropsis sp. at $250^{\circ} \mathrm{C}$ yielded a biooil yield of $30.0 \%$ by weight with the use of nano-Ni/ $\mathrm{SiO}_{2}$ as catalyst. ${ }^{151}$

During torrefaction, the microalgae biomass is degraded at temperatures ranging from $200-300^{\circ} \mathrm{C}$ in inert environments for a few minutes to a few hours. ${ }^{77,145}$ This process ensures that the microalgae gains in calorific values and yields a charry solid. Investigations on the effects of this technique are already available. ${ }^{152}$ Pyrolysis is similar to torrefaction but works at higher temperatures such as $400-600^{\circ} \mathrm{C}$. However, the temperature varies with respect to the time allocated to the process. The main products are bio-oil, charcoal and gaseous fractions. ${ }^{153}$ Bio-oil was produced at $57.9 \%$ during flash pyrolysis of Chlorella protothecoides at $450^{\circ} \mathrm{C} .154$ Pyrolysis of $S$. platensis produced bio-oil at a yield of $29 \%$ at $500^{\circ} \mathrm{C}$ compared to $23 \%$ at $350^{\circ} \mathrm{C}$ indicating temperature differences affect the yield. ${ }^{155}$

Gasification is the conversion of microalgae onto $\mathrm{H}_{2}, \mathrm{CO}, \mathrm{CH}_{4}$ and other combustible gases. This technology can be divided into two types: conventional gasification and supercritical water gasification. ${ }^{145}$ Gasification of microalgae Nannochloropsis gaditana was performed successfully at an efficiency of $97.4 \%$ with the production of hydrogen, methane and carbon dioxide at $52 \%, 17.9 \%$ and $23 \%$ respectively. ${ }^{156}$ Despite the good production values, it should be noted that such operations require high energy input to generate high temperatures and thus can be regarded as economically not viable.

\section{Waste water for improved biofuel production}

The use of microalgae for waste water treatment can be considered as phytoremediation as it is the decontamination of waste-waters of pollutants or removal of xenobiotics. Waste waters can be in the form of municipal waste waters, agricultural rejects, and industrial discharges. Excessive nutrients can be removed by growing microalgae or macroalgae. ${ }^{84}$ Medium containing fermented swine urine as waste-water was used to grow Scenedesmus sp. for phycoremediation. The growth rate was improved by 3 folds and secondary metabolite production was also increased (astaxanthin by 2.8 folds and $\beta$ carotene by more than 5 folds). ${ }^{157}$ Nannochloropsis salina was tested as a candidate to decompose organic matter in anaerobic digestion. Maximum biomass production was evaluated at $92 \mathrm{mg} / \mathrm{L} / \mathrm{d}$ when $6 \%$ of effluent was used. ${ }^{18}$ The use of waste waters is an appealing alternative source of nutrients for microalgae culture but specific conditions should be met for the culture to be successful. The nitrogen concentration is crucial in microalgae culture as its presence in high quantities ensures the uptake of phosphorus. ${ }^{106}$ The culture of Chlorella vulgaris in agricultural waste products under mixotrophic conditions yielded a dry weight of $2.62 \mathrm{~g} / \mathrm{L}$ and a lipid yield of $0.86 \mathrm{~g} / \mathrm{L} .{ }^{113}$ Phycoremediation was also successful with Chlamydomonas debaryana in wastewaters where maximum lipid production was quantified at $87.5 \mathrm{mg} / \mathrm{L} /$ day. ${ }^{158}$ Additionally, waste waters used as blends are cost-effective sources of nutrients suitable for microalgae culture. ${ }^{159}$ This can help reduce the capital investment or use the investments for other purposes.

\section{Economic perspective of microalgae culture and potential improvements}

The concept of using microalgae for biofuels production is very appealing to counter the use of fossil fuels and plant biomass. However, for the time being, the production status is very limited on the industrial scale due to the high production costs associated with the culture and processing of the biomass. ${ }^{120}$ The simplest of open pond culture systems would cost a minimum of $\$ 100,000$ including all of the processing chain. ${ }^{160}$ When compared, open ponds are way cheaper to build and maintained than photobioreactors but on the other hand, the yield of biomass harvested from photobioreactors is higher. ${ }^{161}$ An eval- uation of a hierarchical control strategy for microalgae culture using photobioreactors has been performed and the cultivation cost was found to reach $100 € / \mathrm{kg}$ and a lowered $\mathrm{CO}_{2}$ loss of $167 \mathrm{~g} / \mathrm{d} .{ }^{162}$

On large scale, microalgae culture costs can still be lowered with the use of inorganic carbon sources. The incorporation of flue gases as $\mathrm{CO}_{2}$ source in photoautotrophy cultures would be a better choice because the carbon is not delivered to the atmosphere. ${ }^{163}$ A Profit and Loss analysis was conducted with Haematococcus pluvialis where production costs dropped by $18 \%$ when water was recycled, solar energy was used as energy source and $\mathrm{CO}_{2}$ flue gas was used. ${ }^{164}$ The inclusion of waste waters as a source of nutrients is also a beneficial way of lowering costs as reviewed in the Waste water for improved biofuel production section. Waste waters contain nitrogen and phosphorus which are the major nutrients for microalgae thus making such a source relevant.

The major economical issues arise with the downstream processes, starting with the harvesting techniques. ${ }^{140}$ Due to the negative charge, small cell size and motility, different techniques are currently used to harvest microalgae such as centrifugation, sedimentation, flocculation and filtration, or combinations of them. ${ }^{164}$ Harvesting microalgal biomass may alone contribute up to $20-30 \%$ and even up to $50 \%$ of the costs in the production chain. ${ }^{165,166}$ Low cost techniques are currently being investigated such as the use of biological flocculants (discussed in the previous sections). At this point, one should bear in mind that downstream processing differs with respect to the expected end product(s). ${ }^{117}$ If the culture is solely for biofuels production, the costs will be less than a culture being performed to generate value-added products such as astaxanthin which will require very expensive processes and equipment.

\section{Genetically engineered microalgae for improved biofuels production}

Modifying microalgae at the genetic levels can be very useful as it may increase the potential of certain strains to produce more lipids or carbohydrates for biofuels production. ${ }^{167}$ For lipids, higher rates of accumulation are being researched through changes in the biochemical pathways. ${ }^{168}$ Some enzymes are being over expressed such as the malic enzyme in microalgae Phaeodactylum tricornutum where the transgenic version yielded a 2.5 -fold of total lipids compared to the wild strain. ${ }^{169}$ Similar results were obtained with Schizochytrium sp. where over-expression of the gene superoxide dismutase (SOD1) 
yielded $32.9 \%$ higher lipids content than the wild type. ${ }^{170}$ Another research with transgenic Chlorella sorokiniana and Chlorella vulgaris has shown that over-expression of gene carbonic anhydrase yielded 2.2-fold of lipid accumulation than that of their respective wild types. ${ }^{168}$

In the case of bioethanol, some microalgae directly synthesize it as a metabolite and research is ongoing in trying to increase the yield. ${ }^{171}$ The insertion of certain genes at specific regions can be very advantageous. This was demonstrated when aldolase was co-over expressed with pyruvate decarboxylase and alcohol dehydrogenase in cyanobaterium Synechocystis PCC 6803 yielding $69 \%$ more ethanol and a higher biomass of $10.1 \%{ }^{172}$ An important aspect of culturing bioethanol producing microalgae is their tolerance to the ethanol as high concentrations can be toxic to the cells. One example is recombinant cyanobacteria Synechocystis UL 030, which was engineered with 2 cassettes of genes per genome to become more tolerant to ethanol than its wild type. ${ }^{173}$

Such experiments and findings demonstrate the capacity of transgenic microalgae in the production of biodiesel and bioethanol. However, even though this application seems appealing, great care should be taken when handling genetically modified organisms as they do not exist naturally. Cyanobacteria have the potential of transferring genes horizontally with unrelated microbes and this will require thorough assessments to evaluate the harm caused to the environment in case they manage to thrive there. ${ }^{174}$ Therefore, culturing modified microalgae will require intense supervision to avoid their introduction into surrounding ecosystems.

\section{Exploiting microalgae and residual biomass for other applications Feed production}

With the production of $3^{\text {rd }}$ generation biofuels, other appealing applications of microalgae are being researched as potential sources of phytochemicals, valuable chemicals and food/feed additives. ${ }^{175}$ If compared to plants, microalgae are photosynthetic microorganisms that lack specialized organs such as leaves, vascular tissue, etc. as plants do. ${ }^{16}$ However, when it comes to cellular composition, microalgae can also synthesize lipids, proteins and carbohydrates as well as numerous bioproducts such as vitamins, pigments and antioxidants. ${ }^{92}$ Following extraction of lipids and carbohydrates from biofuels production, there is the output of residual biomass which would consist mainly of proteins and potentially, other molecules in the form of vitamins, pigments and antioxidants.

Research with Scenedesmus obliquus has shown that the residual biomass can be used as feed for brine shrimp after lipid extraction for biodiesel production. The average fresh weight of the shrimp increased from $3.8 \mathrm{~g}$ to $4.7 \mathrm{~g}$ when residual biomass applied was increased from $0.01 \mathrm{~g} / \mathrm{L}$ to $0.4 \mathrm{~g} / \mathrm{L} .^{148}$ In aquaculture practices, using microalgae as feed has been an ongoing practice for the past decades. Microalgae are important sources of protein likely to replace soybean meal, fish meal and rice bran in feed formulations. ${ }^{90}$ With issues such as fish meal being expensive and not always readily available, other sources of feed need to be investigated and microalgae was identified as a potential source. ${ }^{14}$ Microalgae are an excellent source of feed for fish larvae, molluscs and crustaceans. The quality of the microalgae has a direct impact on the growth rate and reproduction rates of Artemia (brine shrimp). ${ }^{176}$ Nannochloropsis sp, Pavlova lutheri and Isochrysis sp. are some of the microalgaes that are fed to brine shrimp, which are in turn fed to advanced stages of fish larvae and crustaceans. ${ }^{177,178}$

However, it is also essential for microalgae based feed to contain fatty acids such as linoleic acid (18:2w6), linolenic acid (18:3w3), eicosapentaenoic acid (EPA, 20:5w-3), arachidonic acid (ARA, 20:4w6) and docosahexaenoic acid (DHA, 22:6w-3) as well as some essential amino acids such as tryptophan considering that shrimps and fish cannot synthesize them. ${ }^{179}$ Lack of these components in diets may result in poor growth and subsequently in death. Such important fatty acids accumulate in fish/crustaceans through the food chain. ${ }^{180}$ Microalgae are excellent sources of such fatty acids. Investigation using microalgae Porphyridium cruentum demonstrated that EPA was produced at a peak of $13.1 \%$, ARA at $30.5 \%$, linoleic acid at $27.6 \%$ and linolenic acid at $0.4 \%$ (under various conditions). ${ }^{181}$ Microalgaes are also cultured for other marine organisms. Diatoms such as Navicula sp. are fed to juvenile abalone, which are highly appreciated as a seafood delicacy in Asian countries. ${ }^{178,182}$ Microalgae can also serve as ingredients for feed additive production. Incorporating Spirulina platensis to the feed of Oreochromis niloticus (Nile tilapia) as $10 \mathrm{~g} / \mathrm{kg}$ diet improved the growth performance and immunity of the fish. ${ }^{183}$

\section{Bioactive molecules production}

Microalgae have the ability to produce various biomolecules such as astaxanthin, lutein, beta-carotene, chlorophyll as well as fatty acids among many others. ${ }^{14}$ Among the bioactive compounds, some tend to have antimicrobial properties. On the global market, the number of effective antimicrobial drugs is gradually decreasing with the increase in antimicrobial resistance. ${ }^{184,185}$ This fact has been known for a long time and many mechanisms allowing the antibiotic resistance to occur in bacteria have been identified. ${ }^{186}$ Microalgae such as Chroococcus dispersus, Chlamydomonas reinhardtii and Chlorella vulgaris are known to exhibit antimicrobial activities. ${ }^{187}$ The major and valuable secondary metabolite productions in Scenedesmus sp. are astaxanthin and $\beta$-carotene. ${ }^{157}$ Astaxanthin is also produced from $H$. pluvialis at a rate of $1.5-3 \%$ of the dry weight and is considered as high-value carotenoid. ${ }^{163}$ It provides very good protection for the membrane phospholipids. Additionally, this molecule offers health benefits such as anticancer, anti-inflammatory and immune-modulating functions. ${ }^{188} \mathrm{D}$. salina production is currently at 1200 tons per annum in Australia. Israel, USA and Japan for the production of various valuable goods such as $\beta$ carotene. ${ }^{189}$ At a closer look, biofuels production from microalgae can simultaneously lead to various business opportunities as they contain such value-added products. ${ }^{121}$

\section{Conclusions}

Biofuels such as bioethanol and biodiesel are predominantly produced from biomass for the transport sector. Their introduction as a source of energy was initiated from the controversies associated with the use of fossil fuels such as carbon dioxide emission, global warming and the fact that they are a finite source of energy. The production of these biofuels from sugarcane, corn, soybean and palm is already at the industrial scale. Their use alleviates the issues associated with gasoline and diesel but they are in turn subject competition for food, land for agriculture and increasing food prices. The same problems were identified when biofuels were being produced from non-food crops (Arundo donax and Jatropha curcas) and attempts are being made to improve processes for higher yields.

In the mean time, microalgae were found as a potential source of same biofuels. These algae have a much higher growth rate compared to plants and need only 2Mha of land to produce $136900 \mathrm{~L} /$ ha of biodiesel. The culture of microalgae can be done in open ponds, closed systems and photobioreactors but need to be economically viable. Microalgae do not require fertile land and thus does not compete for food 
production. Other advantages of microalgae are their ability to produce high yields of lipids and carbohydrates when subjected to stress conditions and to thrive in waste waters. For liquid biofuels, microalgae biomass is processed through two main processes such as chemical and biochemical techniques which yield biodiesel and ethanol respectively. However, the use of microalgae for biofuels is limited due to the costs associated with the implementation and production. Improvements in the biomass processing techniques and culture parameters need to be brought to make this field relevant and economically feasible.

\section{References}

1. Zou C, Zhao Q, Zhang G, Xiong B. Energy revolution: From a fossil energy era to a new energy era. Natural Gas Industry B 2016;3:1-11.

2. Worldometers. Current World Population. 2018. Available from: http://www.worldometers.info/worldpopulation/. Accessed: April 2018.

3. Rabourdin S. Vers une nouvelle révolution enérgétique? France: Le Cavalier Bleu; 2011.

4. International Energy Agency (IEA). Market Report Series: Oil 2017, Analysis and forecasts to 2022. IEA; 2017. $147 \mathrm{p}$.

5. Lackner KS. Chapter 1- Comparative impacts of fossil fuels and alternative energy sources. In: Carbon Capture: Sequestration and Storage. The Royal Society of Chemistry; 2009. pp 1-40. Available from: http://dx.doi.org/10.1039/9781847559 715-00001.

6. Union of concerned Scientists (UCS). Causes of Sea Level Rise: What the Science Tells Us, 2013. Available from: www.ucsusa.org/sealevelrisescience

7. Ahuja S. Food, energy, and water: the chemistry connection. Amsterdam; Boston: Elsevier; 2015.

8. Hansen J, Ruedy R, Sato M, Lo K. Global surface temperature change. Rev Geophys 2010;48.

9. Foidl N, Foidl G, Sanchez M, et al. Jatropha curcas L. as a source for the production of biofuel in Nicaragua. Bioresource Technol 1996;58:77-82.

10. Moreira JR. Sugarcane for energy recent results and progress in Brazil. Energy Sustain Dev 2000;4:43-54.

11. Scordia D, Cosentino SL, Lee J-W, Jeffries TW. Bioconversion of giant reed (Arundo donax L.) hemicellulose hydrolysate to ethanol by Scheffersomyces stipitis CBS6054.
Biomass Bioenergy 2012;39:296-305.

12. Chisti Y. Biodiesel from microalgae. Biotech Adv 2007;25:294-306.

13. Gualtieri P, Barsanti L. Algae: Anatomy, Biochemistry, and Biotechnology. Boca Raton: Taylor \& Francis; 2006.

14. Yaakob Z, Ali E, Zainal A, et al. An overview: biomolecules from microalgae for animal feed and aquaculture. $\mathrm{J}$ Biol Res-Thessalon 2014;21:6.

15. Adenle AA, Haslam GE, Lee L. Global assessment of research and development for algae biofuel production and its potential role for sustainable development in developing countries. Energ Policy 2013;61:182-95.

16. Alam F, Date A, Rasjidin R, et al. Biofuel from Algae- Is it a viable alternative? Procedia Engineer 2012;49:221-27.

17. Demirbas A. Use of algae as biofuel sources. Energ Convers Manage 2010;51:2738-49.

18. Cai T, Park SY, Racharaks R, Li Y. Cultivation of Nannochloropsis salina using anaerobic digestion effluent as a nutrient source for biofuel production. Appl Energ 2013;108:486-92.

19. Capellán-Pérez I, Mediavilla M, de Castro C, et al. Fossil fuel depletion and socio-economic scenarios: An integrated approach. Energy 2014;77:64166.

20. British Petroleum (BP). Statistical Review of World Energy June 2017. British Petroleum; 2017. Available from: https://euagenda.eu/publications/bp-statistical-review-of-worldenergy-june-2017.

21. International Energy Agency (IEA). World Energy Outlook (WEO). Executive Summary. China and India Insights. IEA; 2007. Available from: http://www.iea.org/Textbase/npsum/W EO2007SUM.pdf.

22. Alves DC, Rodrigo De Losso da Silveira B. Short-run, long-run and cross elasticities of gasoline demand in Brazil. Energ Econ 2003;25:191-9.

23. Ben Sita B, Marrouch W, Abosedra S. Short-run price and income elasticity of gasoline demand: Evidence from Lebanon. Energ Policy 2012;46:10915.

24. Sene SO. Estimating the demand for gasoline in developing countries: Senegal. Energ Econ 2012;34:189-94.

25. Taghvaee VM, Hajiani P. Price and income elasticities of gasoline demand in Iran: using static, ECM, and dynamic models in short, intermediate, and long run. Modern Econ 2014;5:939_ 50 .
26. Zecca A, Chiari L. Fossil-fuel constraints on global warming. Energ Policy 2010;38:1-3.

27. International Energy Agency (IEA). $\mathrm{CO} 2$ emissions from fuel combustion highlights 2017. IEA; 2017.

28. International Energy Agency (IEA). $\mathrm{CO} 2$ emissions from fuel combustion highlights 2015. IEA; 2015.

29. World Health Organisation (WHO). Burden of disease from ambient air Pollution for 2012. WHO; 2014. Available from: http://www.who.int/gho/phe/outdoor_a ir_pollution/burden/en/.

30. The National Aeronautics and Space Administration. Global climate change: Vital signs of the planet. NASA, 2019. Available from: https://climate.nasa.gov/vitalsigns/sea-level/ Accessed: February 2019.

31. Mundaca G. How much can $\mathrm{CO} 2$ emissions be reduced if fossil fuel subsidies are removed? Energ Econ 2017;64:91104.

32. Parry I, Veung C, Heine D. How much carbon pricing is in countries' own interests? The critical role of co-benefits. Climate Change Econ 2015;6:1550019-1-26.

33. United Nations (UN). Kyoto Protocol to the UN framework convention on climate change. UN; 1998. Available from: https://unfecc.int/process/thekyoto-protocol.

34. European Commission (EC). Communication from the Commission to the European Parliament and the Council. The Paris Protocol - A Blueprint for tackling Global Climate Change beyond 2020. EC; 2015.

35. Salter R, Newman P, Dhar S. Technical University of Denmark RNL for SEURC on E Climate and Sustainable Development. Technologies for climate change mitigation - Transport sector. UNEP; 2011.

36. European Federation for Transport and Environment (EFTE). Reducing $\mathrm{CO} 2$ emissions from new cars. EFTE; 2007. Available from: https:/www.transportenvironment.org/docs/Publications /2007/2007-09_progress _ voluntary_commitment_2006.pdf.

37. Creutzig F, McGlynn E, Edenhofer O. Climate policies for road transport revisited (I) : Evaluation of the current framework. Energ Policy 2011;39:2396-406.

38. Polcar A, Žák M, Čupera J, Sedlák P. Effect of biofuel E85 combustion on fuel consumption in spark-ignition engines. Acta Universitatis 
Agriculturae et Silviculturae Mendelianae Brunensis. 2012;6017380.

39. Hassan MH, Kalam MA. An Overview of Biofuel as a Renewable Energy Source: Development and Challenges. Procedia Engin 2013;56:39-53.

40. Bull SR. Renewable alternative fuels: alcohol production from lignocellulosic biomass. Renew Energ 1994;5:799-806.

41. Murty PSR. Renewable Energy Sources. In: Electrical Power Systems. Elsevier; 2017. Available from: http://linkinghub.elsevier.com/retrieve/ pii/B9780081011249000243.

42. Galbe M, Zacchi G. Production of ethanol from lignocellulosic materials. In: Cortez LAB (ed) Sugarcane bioethanol - R\&D for Productivity and Sustainability. Blucher, São Paulo; 2014. Available from: http://openaccess.blucher.com.br/articledetails/19278.

43. Gustavsson L, Bijrjesson P, Johansson $\mathrm{B}$, Svenningsson P. Reducing $\mathrm{CO} 2$ emissions by substituting biomass for fossil fuels. Energy 1995;20:1097-113.

44. Murphy DJ. Biofuels from Crop Plants. Energy Crops; 2003.

45. Meller E, Green U, Aizenshtat Z, Sasson Y. Catalytic deoxygenation of castor oil over $\mathrm{Pd} / \mathrm{C}$ for the production of cost effective biofuel. Fuel 2014;133:89-95.

46. United States of America Department of Energy. Clean Cities Alternative Fuel Price Report. U.S Department of Energy; 2018. Available from: https://www.afdc.energy.gov/uploads/ publication/alternative_fuel_price_rep ort_jan_2018.pdf.

47. Wang $\bar{Q}$, Tian Z. Biofuels and the policy implications for China: Biofuel. Asian-Pac Econ Liter 2011;25:161-8.

48. Lebel L, Lorek S, Daniel R. Sustainable production consumption systems: knowledge, engagement, and practice. Dordrecht, New York: Springer; 2010.

49. Gheewala SH, Damen B, Shi X. Biofuels: economic, environmental and social benefits and costs for developing countries in Asia: Biofuels: economic, environmental and social benefits. Wires Clim Change 2013;4:497511.

50. Food and Agriculture Organisation (FAO). Biodiversity for Food and Agriculture. Contributing to food security and sustainability in a changing world. FAO; 2011.

51. Hall DO, House JI. Biomass: a modem and environmentally acceptable fuel.
Sol Energ Mat Sol C 1995;38:521-42.

52. Kojima M, Johnson T. Biofuels for transport in developing countries: socioeconomic considerations. Energy Sustain Dev 2006;10:59-66.

53. Baier SL, Clements M, Griffiths CW, Ihrig JE. Biofuels Impact on Crop and Food Prices: Using an Interactive Spreadsheet. SSRN Electronic Journal; 2009. Available from: https://www.federalreserve.gov/pubs/ifdp/2009/967/ifd p967.pdf.

54. Fargione JE, Plevin RJ, Hill JD. The Ecological Impact of Biofuels. Ann Rev Ecol S 2010;41:351-77.

55. Pacca S, Moreira JR. A Biorefinery for Mobility? Environ Sci Technol 2011;45:9498-505.

56. Bogdanski A. Integrated food-energy systems for climate-smart agriculture. Agric \& Food Security 2012;1:9.

57. Food and Agriculture Organisation (FAO). The impact of disasters on agriculture and food security. FAO; 2015. Available

from: http://www.fao.org/resilience/resource s/resources-detail/en/c/346258/.

58. Uitto JI, Shaw R. Sustainable development and disaster risk reduction. (Disaster risk reduction). Springer; 2016.

59. Claassen PAM, van Lier JB, Lopez Contreras AM, et al. Utilisation of biomass for the supply of energy carriers. Appl Microbiol Biot 1992;52:74155.

60. Ask M, Olofsson K, Di Felice T, et al. Challenges in enzymatic hydrolysis and fermentation of pretreated Arundo donax revealed by a comparison between SHF and SSF. Process Biochem 2012;47:1452-9.

61. Draude KM, Kurniawan CB, Duff SJB. Effect of oxygen delignification on the rate and extent of enzymatic hydrolysis of lignocellulosic material. Bioresource Technol 2001;79:113-20.

62. Chen H. Chemical composition and structure of natural lignocellulose. In: Biotechnology of Lignocellulose. Dordrecht: Springer; 2014.

63. Shahzadi T, Mehmood S, Irshad M, et al. Advances in lignocellulosic biotechnology: A brief review on lignocellulosic biomass and cellulases. Adv Biosci Biotechnol 2014;5:246-51.

64. Iqbal HMN, Kyazze G, Keshavarz T. Advances in the valorization of lignocellulosic materials by biotechnology: An overview. BioResources 2013;8:3157-76.

65. Cardona CA, Quintero JA, Paz IC. Production of bioethanol from sugarcane bagasse: Status and perspectives.
Bioresource Technol 2010;101:4754 66.

66. Bu L, Xing Y, Yu H, Gao Y, Jiang J. Comparative study of sulfite pretreatments for robust enzymatic saccharification of corn cob residue. Biotechnol Biofuels 2012;5:87.

67. Lau MW, Dale BE. Cellulosic ethanol production from AFEX-treated corn stover using Saccharomyces cerevisiae 424A(LNH-ST). P Nat A Sci 2009; 106:1368-73.

68. Shuai L, Yang Q, Zhu JY, et al. Comparative study of SPORL and dilute-acid pretreatments of spruce for cellulosic ethanol production. Bioresource Technol 2010;101:310614.

69. Zhang DS, Yang Q, Zhu JY, Pan XJ. Sulfite (SPORL) pretreatment of switchgrass for enzymatic saccharification. Bioresource Technol 2013;129:127-34.

70. Chiaramonti D, Prussi M, Ferrero S, et al. Review of pretreatment processes for lignocellulosic ethanol production, and development of an innovative method. Biomass Bioen 2012;46:2535 .

71. Kasavi C, Finore I, Lama L, et al. Evaluation of industrial Saccharomyces cerevisiae strains for ethanol production from biomass. Biomass Bioen 2012;45:230-8.

72. Brethauer S, Wyman CE. Review: Continuous hydrolysis and fermentation for cellulosic ethanol production. Bioresource Technol 2010;101:486274.

73. Sims R, Taylor M. From 1st to 2 nd Generation Biofuel Technologies: An overview of current industry and RD\&D activities. Biofuel Technologies. IEA Bioenergy, France; 2008.

74. Limayem A, Ricke SC. Lignocellulosic biomass for bioethanol production: Current perspectives, potential issues and future prospects. Prog Energ Combust 2012;38:449-67.

75. Kafuku G, Mbarawa M. Biodiesel production from Croton megalocarpus oil and its process optimization. Fuel 2010;89:2556-60.

76. Chisti Y. Biodiesel from microalgae beats bioethanol. Trends Biotechnol 2008;26:126-31.

77. Phusunti N, Phetwarotai W, Tekasakul S. Effects of torrefaction on physical properties, chemical composition and reactivity of microalgae. Korean J Chem Eng 2018;35:503-10.

78. Atabani AE, Silitonga AS, Badruddin IA, et al. A comprehensive review on 
biodiesel as an alternative energy resource and its characteristics. Renew Sustain Ener Rev 2012;16:2070-93.

79. Hill J, Nelson E, Tilman D, et al. Environmental, economic, and energetic costs and benefits of biodiesel and ethanol biofuels. P Natl Acad Sci USA 2006;130:11206-10.

80. FAOSTAT. Crops Statistics. Available $\begin{array}{llll}\mathrm{f} & \mathrm{r} & \mathrm{O} & \mathrm{m}\end{array}$ http://www.fao.org/faostat/en/\#data/Q C Accessed: May 2018.

81. Prado CMR, Antoniosi Filho NR. Production and characterization of the biofuels obtained by thermal cracking and thermal catalytic cracking of vegetable oils. J Anal Appl Pyrol 2009;86:338-47.

82. Parvizsedghy R, Sadrameli SM, Towfighi Darian J. Upgraded biofuel diesel production by thermal cracking of castor biodiesel. Energ Fuel 2016;30:326-33.

83. Putzig M. Biodiesel Basics. US Department of Energy, Office of Energy Efficiency and Renewable Energy; 2017. Available from: https://afdc.energy.gov/fuels/biodiesel basics.html.

84. Rawat I, Ranjith Kumar R, Mutanda T, Bux F. Dual role of microalgae: Phycoremediation of domestic wastewater and biomass production for sustainable biofuels production. Appl Energ 2011;88:3411-24.

85. Burton T, Lyons H, Lerat Y, et al. A review of the potential of marine algae as a source of biofuel in Ireland. Sustainable Energy Ireland-SEI, 2009. Available from: https://cdn.technologynetworks.com/TN/Resources/PDF/al gae\%20report\%2004\%202009.pdf

86. Ho S-H, Li P-J, Liu C-C, Chang J-S. Bioprocess development on microalgae-based $\mathrm{CO} 2$ fixation and bioethanol production using Scenedesmus obliquus CNW-N. Bioresource Technol 2013;145:142-9.

87. Merz CR, Main KL. Microalgae Bioproduction - Feeds, Foods, Nutraceuticals, and Polymers. In: Kerton FM, Yan N, eds. Fuels, chemicals and materials from the oceans and aquatic sources. Chichester, UK, John Wiley \& Sons Ltd; 2017. pp 83-112.

88. Aouir A, Amiali M, Bitam A, et al. Comparison of the biochemical composition of different Arthrospira platensis strains from Algeria, Chad and the USA. J Food Meas Charact 2017;11:913-23.

89. Phukan MM, Chutia RS, Konwar BK, Kataki R. Microalgae Chlorella as a potential bio-energy feedstock. Appl
Energ 2011;88:3307-12.

90. Becker EW. Micro-algae as a source of protein. Biotechnol Adv 2007;25:20710.

91. Biller P, Ross AB, Skill SC, et al. Nutrient recycling of aqueous phase for microalgae cultivation from the hydrothermal liquefaction process. Algal Res 2012;1:70-6.

92. Efremenko EN, Nikolskaya AB, Lyagin IV, et al. Production of biofuels from pretreated microalgae biomass by anaerobic fermentation with immobilized Clostridium acetobutylicum cells. Bioresource Technol 2012;114:34248.

93. Khili M. Characterization of value added proteins and lipids from microalgae [thesis]. Virginia Polytechnic Institute and State University, USA; 2012. Available from: https://vtechworks.lib.vt.edu/bitstream/handle/10919/49673/khili m t 2013.pdf? sequence $=1$

94. Wang H, Ji C, Bi S, et al. Joint production of biodiesel and bioethanol from filamentous oleaginous microalgae Tribonema sp. Bioresource Technol 2014;172:169-73.

95. Guo H, Daroch M, Liu L, et al. Biochemical features and bioethanol production of microalgae from coastal waters of Pearl River Delta. Bioresource Technol 2013;127:422-8.

96. Kim KH, Choi IS, Kim HM, et al. Bioethanol production from the nutrient stress-induced microalga Chlorella vulgaris by enzymatic hydrolysis and immobilized yeast fermentation. Bioresource Technol 2014;153:47-54.

97. Bhagea R, Puchooa D. Isolation and characterisation of microalgae from University of Mauritius farm for bioethanol production. Asian J Microbiol Biotechnol Environ Sci 2015;17:1065-70.

98. Rodríguez-Maroto JM, Jiménez C, Aguilera J, Niell FX. Air bubbling results in carbon loss during microalgal cultivation in bicarbonate-enriched media: experimental data and process modeling. Aquacult Eng 2005;32:493508.

99. de Mooij T, de Vries G, Latsos C, et al. Impact of light color on photobioreactor productivity. Algal Res 2016;15:32-42.

100. Al-Qasmi M, Raut N, Talebi S, et al. A review of effect of light on microalgae growth. Proceedings of the World Congress on Engineering 2012;4.

101. Pahl SL, Lewis DM, Chen F, King KD. Heterotrophic growth and nutritional aspects of the diatom Cyclotella crypti- ca (Bacillariophyceae): Effect of some environmental factors. J Biosci Bioeng 2010;109:235-9.

102. Thompson PA, Guo M, Harrison PJ, Whyte JN. Effects of variation in temperature. ii. on the fatty acid composition of eight species of marine phytoplankton1. J Phycol 1992;28:488-97.

103. Thompson GA. Lipids and membrane function in green algae. Biochi Biophys Acta (BBA) 1996;1302:1745.

104. Loza V, Perona E, Mateo P. Specific responses to nitrogen and phosphorus enrichment in cyanobacteria: Factors influencing changes in species dominance along eutrophic gradients. Water Res 2014;48:622-31.

105. Sharma KK, Schuhmann H, Schenk PM. High lipid induction in microalgae for biodiesel production. Energies 2012;5:1532-53.

106. Beuckels A, Smolders E, Muylaert K. Nitrogen availability influences phosphorus removal in microalgae-based wastewater treatment. Water Res 2005;77:98-106.

107. Dragone G, Fernandes BD, Abreu AP, et al. Nutrient limitation as a strategy for increasing starch accumulation in microalgae. Appl Energ 2011;88:3331-5.

108. Mayers JJ, Flynn KJ, Shields RJ. Influence of the N:P supply ratio on biomass productivity and timeresolved changes in elemental and bulk biochemical composition of Nannochloropsis sp. Bioresource Technol 2014;169:588-95.

109. Chojnacka K, Marquez-Rocha F-J. Kinetic and stoichiometric relationships of the energy and carbon metabolism in the culture of microalgae. Biotechnology 2014;3:21-34.

110. Lodi A, Binaghi L, Faveri DD, et al. Fed-batch mixotrophic cultivation of Arthrospira platensis (Spirulina) (Cyanophycea) with carbon source pulse feeding. Ann Microbiol 2005;55:181-5.

111. Brennan L, Owende P. Biofuels from microalgae - A review of technologies for production, processing, and extractions of biofuels and co-products. Ren Sustain Energy Rev 2010;14:557-77.

112. Zhan J, Rong J, Wang Q. Mixotrophic cultivation, a preferable microalgae cultivation mode for biomass/bioenergy production, and bioremediation, advances and prospect. Int J Hydrogen Energ 2017;42:8505-17.

113. Mohammad MA, Kalbasi M, Mousavi SM, Ghobadian B. Investigation of mixotrophic, heterotrophic, and 
autotrophic growth of Chlorella vulgaris under agricultural waste medium. Prep Biochem Biotechnol 2016;46:150-6.

114. Larsdotter K. Wastewater treatment with microalgae - A literature review. Vatten 2006;62:31-8. Available from: http://www.tidskriftenvatten.se/wpcontent/uploads/2017/04/48_article_2 125.pdf.

115. Chang J-S, Show P-L, Ling T-C, et al. Photobioreactors. In: Larroche $\mathrm{C}$, Sanroman M, Du G, Pandey A, eds. Current developments in biotechnology and bioengineering. Elsevier; 2017. pp 313-352.

116. Andersen RA. Algal culturing techniques. Burlington, Mass: Elsevier/Academic Press; 2005.

117. Acién F, Molina E, Reis A, et al. Economics of microalgae production. In: Gonzalez-Fernandez C, Munoz R, eds. Microalgae-Based biofuels and bioproducts. Duxford, UK: Woodhead Publishing; 2017. pp 485-503.

118. James SC, Boriah V. Modeling Algae growth in an open-channel raceway. $\mathrm{J}$ Comput Biol 2010;17:895-906.

119. Lee Y-K. Microalgal mass culture systems and methods: Their limitation and potential. J Appl Phycol 2001;13:30715.

120. Suali E, Sarbatly R. Conversion of microalgae to biofuel. Ren Sustain Energy Rev 2012;16:4316-42.

121. Zhang X, Rong J, Chen $\mathrm{H}$, et al. Current status and outlook in the application of microalgae in biodiesel production and environmental protection. Front Ener Res 2014;2:1-15.

122. Carvalho AP, Meireles LA, Malcata FX. Microalgal Reactors: A review of enclosed system designs and performances. Biotechnol Progr 2006;22:1490-506.

123. Xu L, Weathers PJ, Xiong X-R, Liu CZ. Microalgal bioreactors: Challenges and opportunities. Eng Life Sci 2009;9:178-89.

124. Grima EM, Fernandez FGA, Camacho FG, et al. Scale-up of tubular photobioreactors. J Appl Phycol 2000;12:355-68.

125. Ugwu CU, Ogbonna JC, Tanaka H. Characterization of light utilization and biomass yields of Chlorella sorokiniana in inclined outdoor tubular photobioreactors equipped with static mixers. Process Biochem 2005;40:340611.

126. Arbib Z, Ruiz J, Álvarez-Díaz P, Garrido-Pérez C, et al. Long term outdoor operation of a tubular airlift pilot photobioreactor and a high rate algal pond as tertiary treatment of urban wastewater. Ecol Eng 2013;52:143-53.

127. Al hattab M, Ghaly A, Hammoud A. Microalgae harvesting methods for industrial production of biodiesel: critical review and comparative analysis. J Fund Renew Ener Appl 2015;5:1-26.

128. Raheem A, Prinsen P, Vuppaladadiyam $\mathrm{AK}$, et al. A review on sustainable microalgae based biofuel and bioenergy production: Recent developments. J Clean Prod 2018;181:42-59.

129. Granados MR, Acién FG, Gómez C, et al. Evaluation of flocculants for the recovery of freshwater microalgae. Bioresource Technol 2012;118:10210.

130. Wang Z, Hou J, Bowden D, Belovich JM. Evaluation of an inclined gravity settler for microalgae harvesting: Evaluation of an inclined gravity settler for microalgae harvesting. J Chem Technol Biotechnol 2014;89:714-20.

131. Griffiths MJ, van Hille RP, Harrison STL. Lipid productivity, settling potential and fatty acid profile of 11 microalgal species grown under nitrogen replete and limited conditions. J Appl Phycol 2012;24:989-1001.

132. Heasman M, Diemar J, Sushames T, Foulkes L. Development of extended shelf-life microalgae concentrate diets harvested by centrifugation for bivalve molluscs - a summary. Aqualcult Res 2000;31:637-59.

133. Sim T, Goh A, Becker E. Comparison of centrifugation, dissolved air flotation and drum filtration techniques for harvesting sewage-grown algae. Biomass 1988;16:51-62.

134. Chen G, Zhao L, Qi Y, Cui Y-L. Chitosan and its derivatives applied in harvesting microalgae for biodiesel production: An Outlook. J Nanomaterial 2014;1-9.

135. Renault F, Sancey B, Badot P-M, Crini G. Chitosan for coagulation/flocculation processes - An eco-friendly approach. Eur Polym J 2009;45:133748.

136. Rashid N, Rehman MSU, Han J-I. Use of chitosan acid solutions to improve separation efficiency for harvesting of the microalga Chlorella vulgaris. Chem Eng J 2013;226:238-42.

137. Chatsungnoen T, Chisti Y. Harvesting microalgae by flocculation-sedimentation. Algal Res 2016;13:271-83.

138. Salim S, Bosma R, Vermuë MH, Wijffels RH. Harvesting of microalgae by bio-flocculation. J Appl Phycol 2011;23:849-55.

139. Sathe S, Durand PM. A low cost, nontoxic biological method for harvesting algal biomass. Algal Res 2015;11:16972 .

140. Talukder MMR, Das P, Wu JC. Microalgae (Nannochloropsis salina) biomass to lactic acid and lipid. Biochem Eng J 2012;68:109-13.

141. Miranda JR, Passarinho PC, Gouveia L. Pre-treatment optimization of Scenedesmus obliquus microalga for bioethanol production. Bioresource Technol 2012;104:342-8.

142. Huang Y, Hong A, Zhang D, Li L. Comparison of cell rupturing by ozonation and ultrasonication for algal lipid extraction from Chlorella vulgaris. Environ Technol 2014;35:931-7.

143. Florentino de Souza Silva AP, Costa MC, Colzi Lopes A, et al. Comparison of pretreatment methods for total lipids extraction from mixed microalgae. Renew Energ 2014;63:762-6.

144. Hernández D, Riaño B, Coca M, García-González MC. Saccharification of carbohydrates in microalgal biomass by physical, chemical and enzymatic pre-treatments as a previous step for bioethanol production. Chem Eng J 2015;262:939-45.

145. Chen W-H, Lin B-J, Huang M-Y, Chang J-S. Thermochemical conversion of microalgal biomass into biofuels: A review. Bioresource Technol 2015;184:314-27.

146. Azadi P, Brownbridge G, Mosbach S, et al. The carbon footprint and nonrenewable energy demand of algaederived biodiesel. Appl Energ 2014; 113:1632-44.

147. Singh A, Olsen SI. A critical review of biochemical conversion, sustainability and life cycle assessment of algal biofuels. Appl Energ 2011;88:3548-55.

148. Abomohra AE-F, El-Sheekh M, Hanelt D. Pilot cultivation of the chlorophyte microalga Scenedesmus obliquus as a promising feedstock for biofuel. Biomass Bioener 2014;64:237-44.

149. Mostafa SSM, El-Gendy NS. Evaluation of fuel properties for microalgae Spirulina platensis biodiesel and its blends with Egyptian petro-diesel. Arab J Chem 2013;10:S2040-50.

150. Dien BS, Cotta MA, Jeffries TW. Bacteria engineered for fuel ethanol production: current status. Appl Microbiol Biot 2003;63:258-66.

151. Saber M, Golzary A, Hosseinpour M, et al. Catalytic hydrothermal liquefaction of microalgae using nanocatalyst. Appl Energ 2016;183:566-76.

152. Mwangi JK, Lee W-J, Whang L-M, et al. Microalgae oil: algae cultivation and harvest, algae residue torrefaction and diesel 
engine emissions tests. Aerosol Air Qual Res 2015;15:81-98.

153. López Barreiro D, Prins W, Ronsse F, Brilman W. Hydrothermal liquefaction (HTL) of microalgae for biofuel production: State of the art review and future prospects. Biomass Bioener 2013;53:113-27.

154. Miao X, Wu Q. High yield bio-oil production from fast pyrolysis by metabolic controlling of Chlorella protothecoides. J Biotechnol 2004;110:85-93.

155. Jena U, Das KC. Comparative evaluation of thermochemical liquefaction and pyrolysis for bio-oil production from microalgae. Energy Fuels 2011;25:5472-82.

156. Caputo G, Dispenza M, Rubio P, et al. Supercritical water gasification of microalgae and their constituents in a continuous reactor. J Supercritic Fluids 2016;118:163-70.

157. Kim MK, Park JW, Park CS, et al. Enhanced production of Scenedesmus spp. (green microalgae) using a new medium containing fermented swine wastewater. Bioresource Technol 2007;98:2220-8.

158. Arora N, Patel A, Sartaj K, et al. Bioremediation of domestic and industrial wastewaters integrated with enhanced biodiesel production using novel oleaginous microalgae. Environ Sci Pollut R 2016;23:20997-1007.

159. Park S, Kim J, Yoon Y, et al. Blending water- and nutrient-source wastewaters for cost-effective cultivation of high lipid content microalgal species Micractinium inermum NLP-F014. Bioresource Technol 2015;198:388-94.

160. Demirbas A. Production economics of high-quality microalgae. Energ Source, Part B 2017;4:395-401.

161. Wang Y, Ho S-H, Cheng C-L, et al. Perspectives on the feasibility of using microalgae for industrial wastewater treatment. Bioresource Technol 2016;222:485-97.

162. Fernández I, Berenguel M, Guzmán JL, et al. Hierarchical control for microalgae biomass production in photobioreactors. Control Eng Pract 2016;54:246-55.

163. Panis G, Carreon JR. Commercial astaxanthin production derived by green alga Haematococcus pluvialis : A microalgae process model and a techno-economic assessment all through production line. Algal Res 2016;18:175-90.

164. Milledge JJ, Heaven S. A review of the harvesting of micro-algae for biofuel production. Rev Environ Sci Bio
2013;12:165-78.

165. Molina Grima E, Belarbi E-H, Acién Fernández F., et al. Recovery of microalgal biomass and metabolites: process options and economics. Biotechnol Adv 2003;20:491-515.

166. Greenwell HC, Laurens LML, Shields RJ, et al. Placing microalgae on the biofuels priority list: a review of the technological challenges. J Roy Soc Interface 2010;7:703-26.

167. John RP, Anisha GS, Nampoothiri KM, Pandey A. Micro and macroalgal biomass: A renewable source for bioethanol. Bioresource Technol 2011;102:186-93.

168. Lin W-R, Lai Y-C, Sung P-K, et al. Enhancing carbon capture and lipid accumulation by genetic carbonic anhydrase in microalgae. J Taiwan Inst Chem E 2018;93:131-41.

169. Xue J, Niu Y-F, Huang T, et al. Genetic improvement of the microalga Phaeodactylum tricornutum for boosting neutral lipid accumulation. Metab Eng 2015;27:1-9.

170. Zhang S, He Y, Sen B, et al. Alleviation of reactive oxygen species enhances PUFA accumulation in Schizochytrium sp. through regulating genes involved in lipid metabolism. Metab Engin Commun 2018;6:39-48.

171. Doan QC, Moheimani NR, Mastrangelo AJ, Lewis DM. Microalgal biomass for bioethanol fermentation: Implications for hypersaline systems with an industrial focus. Biomass Bioenerg 2012;46:7988.

172. Liang F, Englund E, Lindberg P, Lindblad P. Engineered cyanobacteria with enhanced growth show increased ethanol production and higher biofuel to biomass ratio. Metab Eng 2018;46:51-9.

173. Lopes da Silva T, Passarinho PC, Galriça $\mathrm{R}$, Zenóglio A, Armshaw $\mathrm{P}$, et al. Evaluation of the ethanol tolerance for wild and mutant Synechocystis strains by flow cytometry. Biotechnol Rep 2018;17:137-47.

174. Snow A, Smith V. Genetically Engineered Algae for Biofuels: A Key Role for Ecologists. BioScience 2012;62:765-8.

175. Markou G, Nerantzis E. Microalgae for high-value compounds and biofuels production: A review with focus on cultivation under stress conditions. Biotechnol Adv 2013;31:1532-42.

176. Mohebbi F. The brine shrimp artemia and hypersaline environments microalgal composition: a mutual interaction. Int
J Aquat Sci 2010;1:19-27.

177. Spolaore P, Joannis-Cassan C, Duran E, Isambert A. Commercial applications of microalgae. J Biosci Bioeng 2006;101:87-96.

178. Brown MR. Nutritional value and use of microalgae in aquaculture. Avances en Nutrición Acuícola VI Memorias del VI Simposium Internacional de Nutrición Acuícola 2002;3:281-92.

179. Sorgeloos P, Dhert P, Candreva P. Use of the brine shrimp, Artemia spp., in marine fish larviculture. Aquaculture 2001;200:147-59.

180. Radmer RJ. Algal diversity and commercial algal products. Bioscience 1996;46:263-70.

181. Asgharpour M, Rodgers B, Hestekin J. Eicosapentaenoic acid from Porphyridium cruentum: increasing growth and productivity of microalgae for pharmaceutical products. Energies 2015;8:10487-503.

182. Cook PA. The worldwide abalone industry. Modern Econ 2014;5:1181-6.

183. Ibrahem MD, Mohamed MF, Ibrahim MA. The role of Spirulina platensis (Arthrospira platensis) in growth and immunity of nile tilapia (Oreochromis niloticus) and its resistance to bacterial infection. J Agr Sci 2013;5:109-15.

184. Mudimu O, Rybalka N, Bauersachs T, et al. Biotechnological screening of microalgal and cyanobacterial strains for biogas production and antibacterial and antifungal effects. Metabolites 2014;4:373-93.

185. Srinivasan A, Lopez-Ribot JL, Ramasubramanian AK. Overcoming antifungal resistance. Drug Discover Today: Technol 2014;11:65-71.

186. Courvalin P. Transfer of antibiotic resistance genes between gram-positive and gram-negative bacteria. Antimicrob Agents Ch 1994;38:1447-51.

187. Ghasemi Y, Moradian A, Mohagheghzadeh A, et al. Antifungal and antibacterial activity of the microalgae collected from paddy fields of Iran characterization of antimicrobial activity of Chroococcus disperses. J Biol Sci 2007;7:904-10.

188. Barrow CJ, Shahidi F. Marine nutraceuticals and functional foods. Boca Raton, CRC Press; 2008.

189. Food and Agriculture Organisation (FAO). Algae-based biofuels Applications and co-products. FAO, 2010. Available from: http://www.fao.org/bioenergy/aquaticbiofuels/documents/en/. 